Arq. Bras. Med. Vet. Zootec., v.73, n.6, p.1357-1360, 2021

\title{
Stress induced by pre-slaughter farm conditions in pigs
}

[Estresse induzido pelas condições da fazenda pré-abate em suínos]

\author{
R.O. Rusu(i) , L.I. Ailincai* ${ }^{(\mathbb{D})}$, R.N. Malancus ${ }^{(\mathbb{E})}$ \\ "Ion Ionescu de la Brad" Iasi University of Life Sciences \\ Faculty of Veterinary Medicine - 8, Mihail Sadoveanu Alley, 700489, Iasi, Romania
}

\begin{abstract}
Cortisol is a steroid hormone, one of the glucocorticoids, made in the cortex of the adrenal glands and then released into the blood, which transports it in the entire body. Almost every cell contains receptors for cortisol and so cortisol can have lots of different actions depending on which sort of cells it is acting upon. These effects include controlling the body's blood sugar levels and thus regulating metabolism, acting as an anti-inflammatory product, controlling salt and water balance and influencing blood pressure. The study was conducted over a period of 3 months, between March-August 2020, in 2 swine farms in Iasi county, Romania, on a total of 46 pigs, 3 to 4 months old, both males and females, in order to investigate stress levels in finishing facilities. The study revealed higher levels of cortisol while eosinophil counts severely decreased, changes which are associated with a strong reaction to stress for individuals that were housed in finishing facilities.
\end{abstract}

Keywords: swine, stress, cortisol

\section{RESUMO}

O cortisol é um hormônio esteroide, um dos glicocorticoides, produzido no córtex das glândulas suprarrenais e, em seguida, liberado no sangue, que o transporta por todo o corpo. Quase todas as células contêm receptores para o cortisol e, portanto, ele pode ter muitas ações diferentes, dependendo do tipo de célula sobre a qual atua. Esses efeitos incluem controlar os níveis de açúcar no sangue do corpo e, assim, regular o metabolismo, atuando como um produto anti-inflamatório, controlando o equilíbrio de sal e água e influenciando a pressão arterial. O presente estudo foi realizado durante um período de três meses, entre março-agosto de 2020, em duas granjas de suínos no condado de Iasi, Romênia, em um número total de 46 porcos, de três a quatro meses de idade, machos e fêmeas, a fim de investigar níveis de estresse nas instalações de acabamento. O estudo revelou níveis mais elevados de cortisol, enquanto a contagem de eosinófilos diminuiu severamente, mudanças que são consideradas associadas a uma forte reação ao estresse para indivíduos que foram alojados em instalações de acabamento.

Palavras-chave: suínos, estresse, cortisol

\section{INTRODUCTION}

Cortisol is a steroid hormone that regulates a wide range of vital processes throughout the body, including metabolism and the immune response. It also has a very important role in helping the body respond to stress.
Cortisol is a steroid hormone, one of the glucocorticoids, made in the cortex of the adrenal glands and then released into the blood, which transports it in the entire body. Almost every cell contains receptors for cortisol and so cortisol can have lots of different actions depending on which sort of cells it is acting upon. These effects include controlling the body's blood sugar levels and thus regulating metabolism, acting as an anti-

*Corresponding author: lailincai@uaiasi.ro

Submitted: March 11, 2021. Accepted: June 11, 2021. 
inflammatory product, controlling salt and water balance and influencing blood pressure (Etim et al., 2013).

The secretion of cortisol is mainly controlled by three inter-communicating regions of the body; the hypothalamus in the brain, the pituitary gland and the adrenal gland, the so called hypothalamicpituitary-adrenal axis. When cortisol levels in the blood are low, the hypothalamus releases corticotrophin-releasing hormone, which causes the pituitary gland to secrete adrenocorticotropic hormone into the bloodstream. High levels of adrenocorticotropic hormone are detected by the adrenal glands and stimulate the secretion of cortisol, causing cortisol blood levels to rise (Shaw et al., 1995). As the cortisol levels rise, they start to block the release of corticotrophinreleasing hormone from the hypothalamus and adrenocorticotropic hormone from the pituitary. As a result, the adrenocorticotropic hormone levels start to drop, which then leads to a drop in cortisol levels, the regulation of cortisol being made by the means of a negative feedback loop (Etim et al., 2013).

Besides its main known functions, cortisol is a hormone that helps the organism progress daily. On the other hand, high levels of cortisol will overload the adrenal glands, with negative effects. Cortisol level is a well-known marker of stress and together with catecholamine discharges, it may have a negative impact by means of neoplastic lesions development (Peres et al., 2014).

The production of high-quality pork has been a constant objective of the pig industry for many years, the main goal being to obtain pigs with high lean percentage and good meat quality traits at the same time. However, this goal has proved difficult to achieve because meat and carcass quality are complex traits and are influenced by many antemortem and postmortem factors, the stress being one of the most important variables that affect carcass quality (Dokmanovic et al., 2015).

The stressful conditions usually associated with pre-slaughter facilities and increased levels of cortisol have a significant impact on the carcass of slaughtered animals (Hambrecht et al., 2004). Assessing the level of cortisol prior slaughtering may offer a new insight on how the meat should be processed to reduce the impact on carcass and to reduce the factors that lead to stress in pigs. Also, it may lead to a new protocol of slaughtering procedures in which one of the main pursuits is the reduction of stress.

\section{MATERIAL AND METHODS}

The study was conducted over a period of 3 months, between March-August 2020, in 2 swine farms in Iasi county, on a total number of 46 pigs, 3 to 4 months old, weighing between $90-110 \mathrm{~kg}$, both males and females, in order to investigate stress levels. From the first farm 22 pigs were included, while in the second farm 24 pigs were taken into study. All animals were of the same origin. Pigs were housed in the finishing facility on partially slatted floors with no significant changes between the facilities and the conducted management among the included farms. Pigs were provided feed and water ad libitum.

Blood samples were collected twice from both farms at intervals of 4 weeks, the inclusion criteria considering clinically healthy swine, without any pathology. The animals were marked using a nonirritative stain in order to keep the same group of swine for both determinations. For each individual, two samples were collected both initially and prior to slaughtering. One of the samples was collected on EDTA and used for hematology, the other one on vacutainers containing a clotting activation factor, for biochemistry. Blood samples were collected from the jugular vein. The hematology samples were analyzed immediately after their collection.

Hematology was performed using Abaxis HM5 Vet Scan automated hematological analyzer. For each case have been determined the following parameters: red blood cells (RBCs), packed cell volume (PCV), hemoglobin, mean corpuscular volume (MCV), mean corpuscular hemoglobin $(\mathrm{MCH})$ and mean corpuscular hemoglobin concentration (MCHC), WBC (white blood cells) and platelets. Also, a blood film was analyzed for each sample using Diff-Quick staining method.

Biochemistry was performed in an accredited laboratory, having been determined the cortisol levels.

Two-tailed Fisher's exact test was used to analyze contingency tables and examine the significance 
of two parameter association. The level of statistical significance was $\mathrm{P}<0.05$.

\section{RESULTS AND DISCUSSION}

Cortisol is produced from cholesterol in the two adrenal glands located on top of each kidney. Cortisol along with epinephrine is best known for its involvement in the "fight-or-flight" response and temporary increase in energy production, at the expense of processes that are not required for immediate survival. The resulting biochemical and hormonal imbalances occur due to a hormonally driven negative feedback loop (Shaw et al., 1995).

High levels of cortisol over a long period of time have a negative impact on individuals. However, sustained or intermittent hypercortisolism may also accompany many medical disorders that stimulate physiologic/non-neoplastic activation of the hypothalamic pituitary adrenal axis; these two entities sharing indistinguishable clinical and biochemical features (Shaw et al., 1995).

Pre-slaughter stress stimulates the two main stress-responsive neuroendocrine systems including the hypothalamus-pituitary-adrenal (HPA) axis and the sympathetic nervous system. The activation of the HPA axis regulates secretion of cortisol in response to stress. Increased levels of serum cortisol are usually related to increased blood glucose and lactate level, resulting in a faster muscle $\mathrm{pH}$ decline, high drip loss, and lightness in pork.7 Previous studies have investigated the association between cortisol level and meat quality. However, we consider that the level of cortisol is not associated with meat quality as this is explained by the fact that the plasma clearance of cortisol is rapid (Peres et al., 2014).

Table 1 reveals base values for cortisol one month before slaughter and pre-slaughter values. There is an increase for the pre-slaughter group values as it is usually noticed an HPA axis activation in high stress conditions (Hambrecht et al., 2004). After first blood collection, 3 individuals exceeded $10 \mu \mathrm{g} / \mathrm{dl}$ cortisol, compared to the second collection of blood where 42 pigs had elevated values. The Two-tailed Fisher's exact test shows there is a very significant statistical correlation between cortisol levels obtained among the two groups taken into study, with $\mathrm{p}=0,0001$.

Table 1. Cortisol levels at the beginning of the study (T0) and 4 weeks later (T1)

\begin{tabular}{lll}
\hline $\begin{array}{l}\text { Time } \\
\text { determination }\end{array}$ & of & $\begin{array}{l}\text { Mean Cortisol levels } \\
(\mu \mathrm{g} / \mathrm{dl})\end{array}$ \\
\hline $\mathrm{T}_{0}$ & $7.76 \pm 0.4$ \\
$\mathrm{~T}_{1}$ & $10.85 \pm 0.9$ \\
\hline
\end{tabular}

Table 2. Hematology results

\begin{tabular}{lllll}
\hline Parameter & $\mathrm{T}_{0}$ & $\mathrm{SD}$ & $\mathrm{T}_{1}$ & $\mathrm{SD}$ \\
\hline RBC $(\times 106 / \mathrm{mm} 3)$ & 6.74 & 0.83 & 6.88 & 0.5 \\
Hemoglobin $(\mathrm{g} / \mathrm{dL})$ & 11.63 & 1.62 & 12.01 & 1.41 \\
Hematocrit $(\%)$ & 34.15 & 4.96 & 35.25 & 4.55 \\
MCV (fL) & 53.26 & 3.11 & 52.30 & 3.02 \\
MCH (pg) & 17.99 & 1.25 & 18.05 & 1.20 \\
MCHC (g/dL) & 33.25 & 1.25 & 33.60 & 1.45 \\
Platelets (×103/mm3) & 356.56 & 91.23 & 320.00 & 96.05 \\
WBC (×103/mm3) & 19.92 & 7.36 & 20.33 & 6.36 \\
Neutrophils $(\%)$ & 71.20 & 9.12 & 77.10 & 11.10 \\
Eosinophils $(\%)$ & 0.12 & 0.06 & 0.02 & 0.01 \\
Lymphocytes $(\%)$ & 24.30 & 8.98 & 24.40 & 8.60 \\
Monocytes $(\%)$ & 2.75 & 1.02 & 2.05 & 1.10 \\
Neutrophil/lymphocyte ratio & 2.80 & 1.12 & 2.10 & 0.85 \\
\hline
\end{tabular}

As far as hematology results are concerned (Table 2 ), only eosinophils values were modified for all individuals, with eosinophil counts showing decreased values, eosinopenia being usually seen in stressed organisms (Averos et al., 2003).
Among the two farms, 43 individuals had normal eosinophilic counts at first blood collection while only 6 when collecting blood prior slaughtering. The study revealed a very significant statistical correlation between eosinophil counts obtained 
after the first blood collection and the preslaughter one. There is also a very significant statistical correlation between increased cortisol levels and decreased eosinophil counts for the preslaughter group with $\mathrm{p}<0.05(\mathrm{p}=0.0001)$.

Other changes that have been observed were anemia in 3 pigs from farm 1 and 2 in farm 2, with leukocytosis seen in 4 cases in farm 1 .

The body's stress-response system is usually selflimiting. Once a perceived threat has passed, hormone levels return to normal. As adrenaline and cortisol levels drop, the body will return to its regular activities (Etim et al., 2013). On the other hand, when stressors are always present and the body constantly feels under attack, that fight-orflight reaction stays turned on. The long-term activation of the stress-response system and the overexposure to cortisol and other stress hormones that follows can disrupt almost all of the body's processes. This puts it at increased risk and impacts all product released for human consumption (McKay and Cidlowsky, 2003).

Long-term preslaughter stress, such as fighting, cold weather, fasting and transit, which occurs 12 to 48 hours prior to slaughter depletes muscle glycogen, resulting in meat which has a higher $\mathrm{pH}$, darker color, and is drier. Short-term acute stress, such as excitement or fighting immediately prior to slaughter, produces lactic acid from the breakdown of glycogen. This results in meat which has a lower $\mathrm{pH}$, lighter color, reduced water binding capacity, and is possibly tougher (Grandin, 1980).

\section{CONCLUSION}

The study revealed higher levels of cortisol while eosinophil counts severely decreased, changes which are considered to be associated with a strong reaction to stress for individuals that were housed in finishing facilities. As prior studies already revealed, the carcass of animals is highly impacted by increased stress reaction and therefore lowering the cortisol levels is of utmost importance. Given the very significant statistical correlation between increased cortisol levels and decreased eosinophil counts for the pre-slaughter group, we may consider that eosinophil count is an important parameter to assess stress and it may be used by itself as it is easier to conduct an hematological determination than a biochemical one.

\section{REFERENCES}

AVEROS, X.; HERRANZ, A.; SANCHEZ, R. et al. Serum stress parameters in pigs transported to slaughter under commercial conditions in different seasons. Vet. Med. Czech., v.52, p.333342, 2003.

DOKMANOVIC, M.; BALTIC, M.Z.; DURIC, J. et al. Correlations among stress parameters, meat and carcass quality parameters in pigs. Asian Austral. J. Anim. Sci., v.28, p.435-441, 2015.

ETIM, N.N.; ENYENIHI, G.E.; WILLIAMS, M.E. et al. Haematological parameters: indicators of the physiological status of farm animals. $\mathrm{Br} J$. Sci., v.10, p.33-45, 2013.

GRANDIN, T. The effect of stress on livestock and meat quality prior to and during slaughter. Int. J. Study Anim. Probl., v.1, p.313-337, 1980.

HAMBRECHT, E.; EISSEN, J.J.; NOOIJEN, R.I.J. et al. Preslaughter stress and muscle energy largely determine pork quality at two commercial processing plants. J. Anim. Sci., v.82, p.14011409, 2004.

McKAY, L.I.; CIDLOWSKI J.A. Pharmacokinetics of corticosteroids. In: KUFE, D.W.; POLLOCK, R.E. WEICHSELBAUM, R.R. et al. (Eds.). Holland-frei cancer medicine. 6.ed. Hamilton, New Zealand: BC Decker, 2003. 2400p.

PERES, L.M.; BRIDI, A.M.; SILVA, C.A. et al. Effect of low or high stress in pre-slaughter handling on pig carcass and meat quality. Rev. Bras. Zootec., v.43, p.363-368, 2014.

SHAW, F.D.; TROUT, G.R.; MCPHEE, C.P. Plasma and muscle cortisol measurements as indicators of meat quality and stress in pigs. Meat Sci., v.39, p.237-246, 1995 